Marija Lakićević ${ }^{1}$, Danijela Pantović ${ }^{*}$, Aleksandra Fedajev ${ }^{2}$

${ }^{1}$ University of Kragujevac, Faculty of Hotel Management and Tourism in Vrnjačka Banja, Serbia University of Belgrade, Technical Faculty in Bor, Serbia

\title{
Investigating Factors of Customer Loyalty Formation for Wellness Spa
}

DOI: 10.7595/management.fon.2021.0031

\begin{abstract}
:
Research question: The objective of this paper is to examine the level of the development of spa tourism with a special review of the wellness tourist offer of the Republic of Serbia, and also which factors of this tourist offer we should pay special attention to and improve, to achieve the highest level of tourist loyalty. Motivation: The tourism potential of the Republic of Serbia has not been sufficiently researched and that served as a basic motivational factor. Idea: Considering the tourist potential that Serbia has and partly the work of Han et al., (2017), the fact that spa tourism is the fastest-growing sector in the entire tourism industry, and that the wellness tourism offer is a very important segment of spa tourism, there is a need to identify factors that influence the visitors' loyalty formation for such tourist destinations. As the Republic of Serbia has a lot of wellness centres, it represents a very convenient location for conducting such research. Data: This research included 298 guests of wellness centres in Vrnjačka Banja: "Solaris", "Aleksandar", "Merkur", "Zepter", "Kralj", "Slatina" and "Iwa Wellness Centre". Data collection was performed during July and August 2019. Methods: The PLS-SEM method was used in this paper to test the defined research hypotheses. Factors that contribute to loyalty and revisit for the wellness and spa tourist destination were investigated, and they were measured by the appropriate number of questions: quality of wellness and spa tourism, the value of wellness and spa services, attraction of wellness and spa tourist destination and satisfaction with wellness and spa tourist destination. All attitudes were measured using a five-point Likert scale. Results: The quality and value of wellness and spa services positively impact the affection for wellness and spa tourist destination and satisfaction with wellness and spa tourist destination, while the attraction of wellness and spa tourist destination positively affects satisfaction with wellness and spa tourist destination and tendency to revisit by tourists. The existence of a positive influence of satisfaction with wellness and spa tourist destination and the desire to revisit the tourist loyalty formation was also shown. Contribution: Improving the quality, value, and effect with the Republic of Serbia as a wellness and spa tourist destination will increase the satisfaction of visitors and their desire to revisit this tourist destination, which will lead to greater loyalty in the future. This will increase the revenue generated from this type of tourism and accelerate local and regional development.
\end{abstract}

Keywords: spa, wellness, tourism, visitors' loyalty, tourist destination, Vrnjačka spa.

JEL Classification: Z32, Z33

\section{Introduction}

Modern trends in the tourism market are moving away from the concept of mass tourism related to destinations located on the seacoast and/or mountain ski resorts (Vukovic et al., 2015; Brandao et al., 2019). Modern tourists are increasingly choosing tourism which will separate them from everyday life and provide them with new experiences and pleasures. So today, spas have become some of the most attractive tourist places that are not exclusively related to health tourism. Spa tourism is the fastest-growing sector in the entire tourism industry (Han et al., 2018; Tomic \& Kosic, 2020). Spa hotels offer accommodation with available individual treatments, massages, and services for spa visitors whose focus is on health and well-being (Han et al., 2019; Szromek \& Wybranczyk, 2019). The Republic of Serbia is extremely rich in thermal and mineral 
resources that are not fully developed and efficiently used (Valjarevic et al., 2018; Ristic et al., 2019; Gulan et al., 2020), so it is necessary to dedicate more attention to the exploitation of these potentials.

Being a relatively new form of health tourism, the wellness industry is increasingly attracting the attention of marketing experts. This industry plays a significant role in tourism because there is an enrichment of the tourist offer through various facilities, related to recreation, beauty, and relaxation, i.e., renewal of the physical and spiritual condition of tourists. It is quite certain that the trend of the "health industry" will mark the tourism of the $21^{\text {st }}$ century (Smith \& Diekmann, 2017). Wellness packages are aimed at the proactive side of users, including their attitude towards disease prevention, health improvement, and maintaining the quality of life (De la Hoz-Correa et al., 2018; Kocic \& Radakovic, 2019). Accelerated pace of life, insufficient physical exercise, pollution, and especially exposure to stress endangered the mental and physical health of people. People tend to look for the way out by using the facilities aimed at a more purposeful use of free time, where wellness is the "answer" to the current needs of modern tourists (Islam, 2012). Today, the wellness concept is the closest to the answer to the needs of modern people regarding health, and it has a harmonious and comprehensive influence on the functioning of the organism. As a new approach in accepting a healthy lifestyle, it includes those facilities and methods that have a positive effect on the sensory, physical, emotional, intellectual, social, aesthetic, and spiritual aspects of a person (Mondok, 2019). In this sense, it can be said that wellness consists of seven basic dimensions: physical, social, emotional, intellectual, professional, spiritual, and environmental dimensions.

Given the intensification of investments in wellness tourism in the Republic of Serbia, it is very important to improve the offer of this type of tourism to increase the number of tourists. Accordingly, numerous authors have examined the phenomena of the spa and wellness concept in the function of tourism development. Some authors conclude that spas in the Republic of Serbia have a significant comparative advantage compared to a large part of Europe, so it is necessary to work intensively on the development of wellness tourism product in Serbian spas, especially in the most visited Vrnjačka spa, which has been engaged in organized tourism development for more than 150 years and is in the second place regarding the number of tourists (Dimitrovski et al., 2019). Numerous authors state that spa and wellness tourism is present in many parts of the country, but that tourists usually visit only well-known spa destinations out of habit (Valjarevic et al., 2017).

The popularity of wellness tourism has increased in recent years due to the development of travelling based on activities, rather than the destination (Ahani et al., 2019). Spa centres in the Republic of Serbia have a great potential to meet the needs and requirements of domestic and foreign tourists who are looking for a complete experience of spa and wellness tourism. It is necessary to innovate the tourism product in the sense for this spa destination to use its full potential. Following the above, the objective of this paper is to identify key factors influencing the tourist loyalty formation for a wellness and spa tourist destination.

\section{Literature Review}

Being a relatively new form of health tourism, the wellness industry is increasingly attracting the attention of marketing experts. As for the other services and products, customers make their decision on the selection of wellness and spa destination according to its quality and value. Topalovic \& Marinkovic (2020) state that modern tourist companies should focus on creating and delivering value to their customers because it represents a significant source of competitive advantage. According to these authors, tourist services can be better viewed and understood if they are analyzed through a multidimensional approach to value because tourists can simultaneously enjoy the functional, social, emotional, and other features of the destination when visiting a destination. Thawornwiriyatrakul \& Meeprom (2020) indicated that the relationship between the perceived quality of service and satisfaction is positive and significant. Loke (2020) confirmed the positive relationship between quality and satisfaction both in the case of medical and wellness tourists.

Affection and satisfaction are positive and significantly related to quality and value, considering that they are results of quality and value (Chua et al., 2015; Peng et al., 2017; Silvestri et al., 2017). Taking into account the importance of the quality of services, Han et al., (2019) emphasize that hotels in spa destinations should actively improve the quality of their spa services by providing pleasant experiences for tourists, increasing their level of satisfaction, and encouraging their desire to revisit the destination.Some authors emphasized that, by visiting the wellness and spa destination, the consumers strive for hedonic experiences and not just its utility (Tsai et al., 2012; Loureiro et al., 2013; Kiatkawsin \& Han, 2017). In addition, Albayrak et al., (2017) and Peng et al., (2017) pointed out that various cognitive factors (e.g., recreation activities, service, quality of atmospherics and food) had a significant impact on consumers' affective responses and that such asso- 
ciations eventually exerted a significant impact on satisfaction. Chua et al., (2015) pointed out that tourists' perception of quality (physical environment, interactional, and outcome quality) and value are essential contributors to inducing their satisfaction.

According to the mentioned relations among quality, value, affection, and satisfaction, the following research hypothesis have been derived:

$\mathrm{H} 1$ : The quality of the wellness tourist offer has a positive impact on the affection towards a wellness tourist destination by visitors.

$\mathrm{H} 2$ : The value of the wellness tourist offer has a positive impact on the affection towards a wellness tourist destination by visitors.

H3: The quality of the wellness tourist offer has a positive impact on the satisfaction of visitors with a wellness tourist destination.

$\mathrm{H} 4$ : The value of the wellness tourist offer has a positive impact on the satisfaction of visitors with a wellness tourist destination.

The role of affective experiences in the tourist decision-making process is very important. Providing tourists with such experiences is becoming a crucial factor of success in wellness and spa tourism (Hashemi et al., 2015; Campon-Cerro et al, 2020). It is especially important for achieving consumer satisfaction (Assaker et al., 2011; Chua et al., 2015). Satisfaction is, on the other hand, often emphasized as an important factor of loyalty (Hashemi et al., 2015). Han et al. (2018) state that there is a significant degree of interdependence between product performances, destination experience, and satisfaction and that these factors allow a satisfactory prediction of destination loyalty. They concluded that satisfaction is of great importance in creating loyalty, as well as that the destination experience and satisfaction also indirectly affect loyalty. Loke (2020) pointed out that the relationship between satisfaction and loyalty is less obvious for wellness tourists in comparison with medical tourists.

Besides its impact on loyalty, tourist satisfaction is also positively correlated with their intentions to revisit.In the marketing literature, but also in the literature related to tourism, a revisit to a destination is considered a very important factor of tourist loyalty, so this factor in customer loyalty forming is very important to analyze, not only in wellness and spa tourism but in all forms of tourism (Sapic et al., 2018). Emphasizing that satisfaction can lead to revisiting and recommending the visited destination to other tourists, Hashemi et al. (2015) believe that spa travel companies should focus on ensuring customer satisfaction. Moreover, a satisfied and returning customer who will share their positive experience with other people is the best advertisement for the least money (Vildova et al., 2015).

Based on the above theoretical and empirical studies regarding the relationship among affect, satisfaction, loyalty, and revisit intentions, the following research hypotheses have been identified:

H5: The affection for wellness tourist destination by visitors has a positive impact on their satisfaction with a wellness tourist destination.

H6: The affection to a wellness tourist destination by visitors has a positive impact on their desire to revisit the destination.

H7: Satisfaction of visitors with wellness tourist destination has a positive impact on their desire to revisit the destination.

H8: Satisfaction of visitors with a wellness tourist destination has a positive impact on the loyalty of visitors. H9: The desire of tourists to revisit wellness tourist destination has a positive impact on their loyalty to the destination.

The defined nine hypotheses will be tested in this study to investigate relations among the mentioned concepts in wellness and spa tourism in the Republic of Serbia.

\section{Methodology}

The PLS-SEM method (Partial Least Squares Structural Equation Modelling) was used in this paper to test the defined research hypotheses. PLS-SEM is a method of modelling structural equations of least squares that is often used in the study of customer attitudes and behaviour. The key advantage of this method is most often that the application of this method effectively explains the variance that predicts the relationships be- 
tween latent variables and maximizes the explained variance. A large number of studies using this methodology in this specific area (Majeed et al., 2018; Lai \& Hitchcock, 2017; Gim, 2018; Zhang \& Xiong, 2020; Afthanorhan et al., 2017), served as motivation for choosing this methodology in the research of the set research hypotheses.

\subsection{Defining latent variables and questionnaires}

In order to investigate the variables that influence customer attitudes and behaviour, and which have been investigated in previous research in this area, an appropriate questionnaire containing the questions from previous studies has been created. The questions were adapted and adjusted based of the results of previous research by Han et al. (2017). Additionally, it should be emphasized that the questions and variables taken from the literature are adapted to the subject of research in this paper - the research of factors that contribute to the wellness services users' loyalty to spa tourism and influence the future customers' behaviour.

This paper investigates five factors that contribute to loyalty, which are measured by an appropriate number of questions (statements): quality of wellness and spa tourism (5 questions), the value of wellness and spa services (2 questions), affection to wellness and spa tourist destination (4 questions) and satisfaction with wellness and spa tourist destination (3 questions), while the tendency to revisit was assessed based on answers to 3 questions. On the other hand, the level of loyalty was assessed based on answers to 4 questions. All attitudes were measured using a five-point Likert scale, where 1 means "I strongly disagree" and 5 means "I strongly agree". In addition to these questions, the questionnaire contains six questions related to the demographic characteristics of the respondents regarding gender, age, the country in which they live, the environment in which they grew up, and where they now live (urban or rural) and employment status.

\subsection{Data collection}

This research included 322 guests of wellness centres in Vrnjačka spa: "Solaris", "Aleksandar", "Merkur", "Zepter", "Kralj", "Slatina" and "Iwa Wellness Centre". This spa is selected since it is one of the largest tourist centres in the Republic of Serbia which has a significant number of wellness spa hotels. Before completing the questionnaire, the participants were given a detailed explanation of the research and the objectives of the research. Data collection was performed during July and August 2019, when traditionally there is the highest concentration of tourists. The initial sample size was 322 subjects, however, 24 respondents had missing data, and so they were not included into the analysis. The analysis was performed on a sample of 298 respondents.

\subsection{Sample structure}

There are slightly more women in the sample (56.5\%) than men (43.5\%). Regarding the age structure, it can be said that the largest number of respondents are aged 31 to 40 (33.6\%). There were $23.5 \%$ respondents aged 19 to $30,23.2 \%$ aged 41 to $50,10.7 \%$ aged 51 to 60 , while the least represented were respondents under the age of $18(3 \%)$. The majority of respondents grew up in an urban environment $(71.5 \%)$ and currently live in such an environment (87.5\%). The largest number of respondents is from Serbia (78\%) and there is a smaller number of respondents from other countries (22\%). It should also be noted that the majority of respondents were employed (65.8\%), $15.1 \%$ were unemployed, $9.7 \%$ work occasionally, while the smallest number of respondents were retired (9.3\%). Finally, data on the number of respondents by wellness centres where the survey was conducted should be provided. Most respondents stayed in the wellness centre "Solaris" (47\%), 20.1\% in "Merkur", 11.7\% in "Aleksandar", 8.1\% in "Kralj", 5.7\% in Iwa Wellness Centre, and the least number of respondents stayed in the "Zepter" (1.3\%).

\section{Results}

Based on a review of the literature, it can be concluded that numerous factors affect loyalty and revisiting the wellness centre, however, for research purposes the authors used the theoretical model which is proposed by Han et al. (2017) and which is shown in Figure 1. 


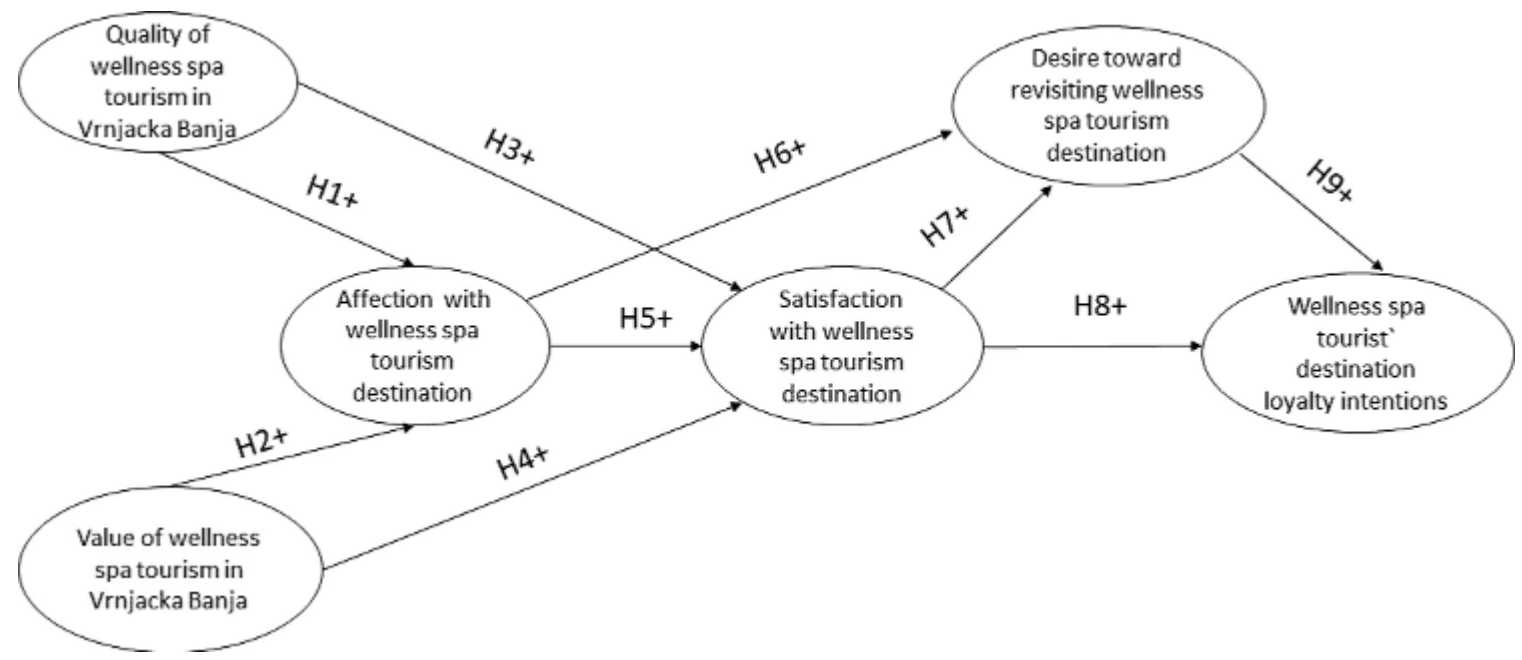

Figure 1: Theoretical model

The Smart PLS 3 software package was used to assess the model parameters. The model measurements were evaluated based on the standardized square root of the average residual square - SRMR, Chi-Square, shown in Table 1.

Table 1: Model measurements

\begin{tabular}{|c|c|c|}
\hline $\begin{array}{c}\text { Model fitting } \\
\text { indicators }\end{array}$ & The value of the indicator & $\begin{array}{c}\text { Recommended } \\
\text { values }\end{array}$ \\
\hline SRMR & 0.032 & $<0.08$ \\
\hline Chi-Square/df & 2.758 & $<3$ \\
\hline NFI & 0.888 & $>0.9$ \\
\hline
\end{tabular}

Based on the results in Table 1, it can be concluded that the obtained results show a satisfactory level of fitting in the proposed model. Primarily, SRMS is 0.032 which is less than the recommended value, ChiSquare/df is less than 3, while NFI is slightly lower than the recommended limit of 0.9.

To assess the validity of the model, the value of Cronbach's Alphas was calculated by the corresponding $\mathrm{p}$-values, and the results are shown in Table 2.

Table 2: Cronbach's Alpha value

\begin{tabular}{|c|c|c|c|c|c|}
\hline Variables & $\begin{array}{c}\text { Original } \\
\text { Sample (O) }\end{array}$ & $\begin{array}{c}\text { Sample Mean } \\
\text { (M) }\end{array}$ & $\begin{array}{c}\text { Standard Deviation } \\
\text { (STDEV) }\end{array}$ & $\begin{array}{c}\text { T Statistics } \\
(\mid \mathbf{O} / \text { STDEV |) }\end{array}$ & P Values \\
\hline Affection & 0.935 & 0.935 & 0.009 & 104.355 & 0.000 \\
\hline Loyality & 0.926 & 0.925 & 0.012 & 77.612 & 0.000 \\
\hline Quality & 0.918 & 0.917 & 0.014 & 65.106 & 0.000 \\
\hline Revisiting & 0.944 & 0.944 & 0.009 & 101.266 & 0.000 \\
\hline Satisfaction & 0.943 & 0.942 & 0.010 & 94.464 & 0.000 \\
\hline Value & 0.911 & 0.910 & 0.021 & 42.423 & 0.000 \\
\hline
\end{tabular}

Based on the data in Table 2, it can be seen that the model is valid, having in mind that all Cronbach's Alpha values are higher than 0.7 (Nannally, 1978) and statistically significant at the level of $p<0.05$. As an additional measure of validity, the value of the average variance extracted (AVE) was calculated and the results are shown in Table 3. 
Table 3: Value of average variance extracted (AVE)

\begin{tabular}{|c|c|c|c|c|c|}
\hline Variables & $\begin{array}{c}\text { Original } \\
\text { Sample O) }\end{array}$ & $\begin{array}{c}\text { Sample } \\
\text { Mean (M) }\end{array}$ & $\begin{array}{c}\text { Standard Deviation } \\
\text { (STDEV) }\end{array}$ & $\begin{array}{c}\text { T Statistics } \\
(\mid \mathbf{O} / \text { STDEV|) }\end{array}$ & P Values \\
\hline Affection & 0.784 & 0.783 & 0.025 & 31.895 & 0.000 \\
\hline Loyality & 0.770 & 0.768 & 0.028 & 27.262 & 0.000 \\
\hline Quality & 0.692 & 0.691 & 0.039 & 17.547 & 0.000 \\
\hline Revisiting & 0.850 & 0.850 & 0.023 & 37.631 & 0.000 \\
\hline Satisfaction & 0.846 & 0.846 & 0.024 & 35.458 & 0.000 \\
\hline Value & 0.838 & 0.837 & 0.035 & 23.911 & 0.000 \\
\hline
\end{tabular}

From Table 3 it can be concluded that according to this indicator the model is also valid, considering that all AVE values are higher than 0.5 and statistically significant at the level of $p<0.05$.

After checking the fitting and validity of the model, the calculation of the values of the regression coefficients was performed, and the initial results of the PLS-SEM model are shown in Figure 2.

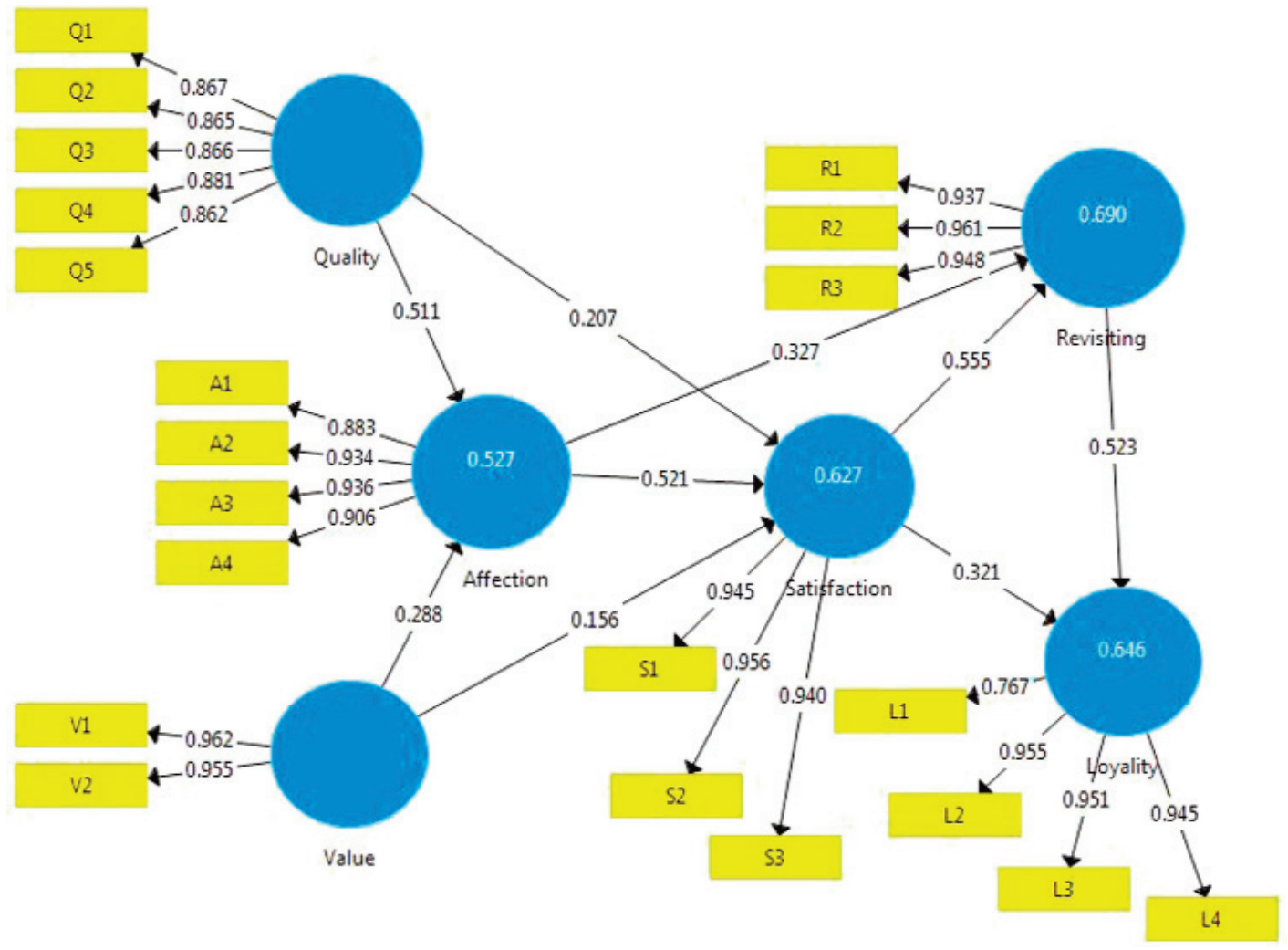

Figure 2: Initial results of the PLS-SEM model

Based on the results presented in Figure 2, it can be concluded that all regression coefficients are positive, as defined in the research hypotheses. However, in order to test the set hypotheses, it is necessary to calculate the appropriate $p$-values for all regression coefficients, which determines the statistical significance of the obtained coefficients. Table 4 shows the results of the bootstrapping process.

Table 4: Regression coefficients after the bootstrapping process

\begin{tabular}{|c|c|c|c|c|c|}
\hline & $\begin{array}{c}\text { Original } \\
\text { Sample (O) }\end{array}$ & $\begin{array}{c}\text { Sample } \\
\text { Mean (M) }\end{array}$ & $\begin{array}{c}\text { Standard Deviation } \\
(\mathbf{S T D E V})\end{array}$ & $\begin{array}{c}\text { T Statistics } \\
(|\mathbf{O} / \mathbf{S T D E V}|)\end{array}$ & P Values \\
\hline Affection $\rightarrow$ Revisiting & 0.327 & 0.328 & 0.065 & 5.000 & 0.000 \\
\hline Affection $\rightarrow$ Satisfaction & 0.521 & 0.520 & 0.066 & 7.903 & 0.000 \\
\hline Quality $\rightarrow$ Affection & 0.511 & 0.508 & 0.074 & 6.934 & 0.000 \\
\hline Quality $\rightarrow$ Satisfaction & 0.207 & 0.213 & 0.072 & 2.863 & 0.004 \\
\hline Revisiting $\rightarrow$ Loyality & 0.523 & 0.523 & 0.069 & 7.531 & 0.000 \\
\hline Satisfaction $\rightarrow$ Loyality & 0.321 & 0.321 & 0.075 & 4.280 & 0.000 \\
\hline Satisfaction $\rightarrow$ Revisiting & 0.555 & 0.553 & 0.065 & 8.491 & 0.000 \\
\hline Value $\rightarrow$ Affection & 0.288 & 0.293 & 0.073 & 3.965 & 0.000 \\
\hline Value $\rightarrow$ Satisfaction & 0.156 & 0.151 & 0.065 & 2.407 & 0.016 \\
\hline
\end{tabular}


The results shown in Table 4 indicate that all regression coefficients are statistically significant at the level of $p<0.05$. Given that the regression coefficient that shows the relation between the quality of the wellness tourist offer in the wellness tourist destination and the effect of this wellness tourist destination by visitors is positive and relatively high (0.511), it can be concluded that hypothesis $\mathrm{H} 1$ is confirmed. A positive regression coefficient $(0.288)$ was also obtained for the relation between the value of the wellness tourist offer and the impact on wellness tourist destination by visitors, based on which it can be concluded that hypothesis $\mathrm{H} 2$ was confirmed.

The next relation that was tested was that between the quality of the wellness tourist offer in the wellness tourist destination and the satisfaction of visitors. A positive regression coefficient of 0.207 was obtained in this case as well, so it can be concluded that hypothesis $\mathrm{H} 3$ was also confirmed, coinciding with the results obtained by Thawornwiriyatrakul \& Meeprom (2020) and Loke (2020). The lowest regression coefficient was obtained for the relation between the value of the wellness tourist offer in the wellness tourist destination and the satisfaction of visitors $(0.156)$. Certainly the obtained positive regression coefficient for the relation between the two mentioned variables indicates that hypothesis $\mathrm{H} 4$ was also confirmed. This confirms the claim of other authors (Chua et al., 2015) that quality and value have a significant impact on satisfaction, and ultimately, on customer loyalty. Within hypothesis $\mathrm{H} 5$, the relation between the affection towards wellness tourist destination by visitors and their satisfaction was examined. A high positive regression coefficient of 0.521 indicates that this hypothesis has been confirmed, confirming the findings obtained by Albayrak et al. (2017) and Peng et al. (2017).

The examination of the relation between the affection towards the wellness tourist destination, as a wellness tourist destination, by visitors and their desire to revisit wellness destination is defined within hypothesis $\mathrm{H} 6$. A positive regression coefficient (0.327) was obtained for this relation, so this hypothesis was also confirmed. The highest regression coefficient in the value of 0.555 was obtained for the relation between the satisfaction of visitors with wellness tourist destination as a wellness tourist destination and their desire to revisit this wellness tourist destination was tested through hypothesis $\mathrm{H} 7$. As a positive regression coefficient was obtained, it can be concluded that this hypothesis was also confirmed. These results confirm the need to improve the tourist affection towards the destination and increase customer satisfaction to increase revisits.

Loyalty is one of the variables that are very often examined in the literature on the attitudes and behaviour of tourists. In this paper, loyalty is analyzed within the last two hypotheses. In that sense, the relation between visitors' satisfaction with a wellness tourist destination and loyalty is defined by hypothesis H8. Given that a positive regression coefficient (0.321) was obtained, it can be concluded that this hypothesis was confirmed, which was pointed out also by Hashemi et al. (2015) and Han et al. (2018). Finally, for the relation between the desire of tourists to revisit a wellness tourist destination and their loyalty to this wellness tourist destination, which was tested under hypothesis $\mathrm{H} 9$, a positive regression coefficient was obtained, so it is concluded that this hypothesis was also confirmed. This result is in line with findings obtained by Hashemi et al. (2015) and Vildova, et al. (2015), indicating that increase in revisits will lead to increased loyalty and attraction of new tourists as a result of sharing the positive experiences by already loyal tourists.

Conclusion

The obtained results of the study confirmed that all analyzed factors (value, quality, experience, satisfaction and revisit) have a positive effect on the formation of loyalty. Although the investigated factors have a significant impact on tourist loyalty, the weakest regression coefficient vas obtained for the relation between the value of the wellness tourist offer and the satisfaction of visitors with this wellness tourist destination, indicating that special attention should be put on increasing the value of wellness tourist destinations offer in the future. Optimizing the tourist offer is of crucial importance for the improvement of wellness tourism, intending to increase the number of tourists who are interested in this type of vacation. This would provide a dynamic local development, boosting the development of other activities that complement the tourist offer in this destination.

This research obtaines significant practical implications for practitioners and wellness spa servise providers considering that it explains the relationships among analysed variables and provides the basis for supply adjustments to meet tourists' needs and maximize business performances, by incresing their loyalty. The findings have implications for the strategic marketing process of both hotels and wellness and spa destinations. An appropriate understanding of tourists' loyalty formation is a key factor in improving inventing marketing strategies for tourist retention and revenue increase in both hotels and tourist destinations. The analyzed model integrated key concepts such as quality and value of wellness spa destination, affection, revisiting, satisfaction, and loyalty and identify inter-relationships among them. Improving the quality and value of destination have a positive impact on affection and satisfaction and further on loyalty creation and post-purchase behavior of tourists. 
The findings have important theoretical implications regarding the fact that they may support and extend the existing theoretical models on tourists' loyalty and their behavioral intentions. Also, it should be taken into account that the role of cognitive and affective processes in increasing motivation and formation of destination loyalty have not been sufficiently covered in previous wellnes tourism literature, so this research is one more piece of the puzzle in this important research area.This study widened and deepened the analysis of the relationship between quality and value, on one side, and loyalty, on the other, by adding additional mediators - affection, satisfaction and revisit.

To deliver guidance for future research in this area, it is important to discuss the limitations of this study. First, this study was conducted in one particular spa in the Republic of Serbia. However, results are to a great extent applicable to other wellness spa destinations in the Republic of Serbia, having in mind that it is one of the greatest tourist centres in the Republic of Serbia. In future studies, it is recommended that the mediating roles of functional and wellness values be examined in a larger sample of diverse settings, including both medical and wellness tourism destinations. The current situation of the pandemic also affects tourism, especially spa tourism and wellness tourism, which cannot function normally during this period. Tourists do not have the opportunity to visit tourist spa wellness destinations regardless of loyalty to a particular place and the future study should investigate the influence of pandemic on spa and wellness tourism loyalty. Researchers should consider performing the same research in pandemic conditions and compare results to indicate the recommendations for improvements of wellness and spa tourism performances in such unfavourable conditions. The future research should also include loyalty of tourists in the wider region not only in one destination and to perform segmentation of tourist in this market, aiming to adjust the tourist offer for identified segments of tourists. This research obtaines significant practical implications for practitioners and wellness spa service providers considering that it explains the relationships among analysed variables and provides the basis for supply adjustments to meet tourists' needs and maximize business performances, by incresing their loyalty. In addition, the findings have also theoretical implications regarding the fact that they may support and extend existing theoretical models on tourists' loyalty and their behavioral intentions.

\section{Acknowledgments}

This research study has been supported by the Republic of Serbia's Ministry of Science and Technological Development.

\section{REFERENCES}

[1] Afthanorhan, A., Awang, Z., \& Fazella, S. (2017). Developing the patients' loyalty model for medical tourism industry: the case of Malaysia. International Journal of Society Systems Science, 9(2), 139-164. DOI: 10.1504/IJSSS.2017.085710

[2] Ahani, A., Nilashi, M., Ibrahim, O., Sanzogni, L., \& Weaven, S. (2019). Market segmentation and travel choice prediction in Spa hotels through TripAdvisor's online reviews, International Journal of Hospitality Management, (80), 52-77. DOI: 10.1016/j.ijhm.2019.01.003

[3] Albayrak, T., Caber, M., \& Oz, E. K. (2017). Assessing recreational activities' service quality in hotels: An examination of animation and spa \& wellness services. Journal of Quality Assurance in Hospitality \& Tourism, 18(2), 218-234. DOI: 10.1080/1528008X.2016.1208550

[4] Assaker, G., Vinzi, V. E., \& O'Connor, P. (2011). Examining the effect of novelty seeking, satisfaction, and destination image on tourists' return pattern: A two factor, non-linear latent growth model. Tourism management, 32(4), 890-901. DOI: 10.1016/j.tourman.2010.08.004

[5] Brandao, F., Breda, Z., \& Costa, C. (2019). Innovation and internationalization as development strategies for coastal tourism destinations: The role of organizational networks. Journal of Hospitality and Tourism Management, 41, 219-230.DOI: 10.1016/j.jhtm.2019.10.004

[6] Campon-Cerro, A. M., Di-Clemente, E., Hernández-Mogollón, J. M., \& Folgado-Fernández, J. A. (2020). Healthy water-based tourism experiences: Their contribution to quality of life, satisfaction and loyalty. International journal of environmental research and public health, 17(6), 1961. DOI: 10.3390/ijerph17061961

[7] Chua, B. L., Lee, S., Goh, B., \& Han, H. (2015). Impacts of cruise service quality and price on vacationers' cruise experience: Moderating role of price sensitivity. International Journal of Hospitality Management, 44, 131-145. DOI: 10.1016/j.ijhm.2014.10.012

[8] De la Hoz-Correa, A., Muñoz-Leiva, F., \& Bakucz, M. (2018). Past themes and future trends in medical tourism research: A co-word analysis. Tourism Management, 65, 200-211. DOI: 10.1016/j.tourman.2017.10.001

[9] Dimitrovski, D., Dzamic, R., Celic, I., Seocanac, M., \& Popovic, M. (2019). Dvadeset godina (1999-2019) visokog obrazovanja u Vrnjackoj Banji- od ideje do ostvarenja. Vrnjacka Banja: Univerzitet u Kragujevcu, Fakultet za hotelijerstvo i turizam u Vrnjackoj Banji.

[10] Gim, T. H. T. (2018). Tourist satisfaction, image, and loyalty from an interregional perspective: An analysis of neighboring areas with distinct characteristics. Sustainability, 10(4), 1283. DOI: 10.3390/su10041283 
[11] Gulan, I., Penjisevic, I., Stajic, J.M., Milenkovic, B., Zeremski, T., Stevanovic, V., \& Valjarevic, A. (2020). Spa environments in central Serbia: Geothermal potential, radioactivity, heavy metals, and PAHs, Chemosphere, (242), 1-9. DOI: 10.1016/j.chemosphere.2019.125171

[12] Han, H., Kiatkawsin, K., Jung, H., \& Kim, W. (2018). The role of wellness spa tourism performance in building destination loyalty: The case of Thailand. Journal of Travel \& Tourism Marketing, 35(5), 595610.DOI: $10.1080 / 10548408.2017 .1376031$

[13] Han, H., Kiatkawsin, K., Kim, W., \& Lee, S. (2017). Investigating customer loyalty formation for wellness spa: Individualism vs. collectivism. International Journal of Hospitality Management, 67, 11-23. DOI:10.1016/j.ijhm.2017.07.007

[14] Han, H., Thuong, P. T. M., Kiatkawsin, K., Ryu, H. B., Kim, J. J., \& Kim, W. (2019). Spa hotels: Factors promoting wellness travelers' post-purchase behaviour. Social Behavior and Personality: an international journal, 47(6), 1-13. DOI: 10.2224/sbp.7605

[15] Hashemi, S. M., Jusoh, J., Kiumarsi, S., \& Mohammadi, S. (2015). Influence factors of spa and wellness tourism on revisit intention: The mediating role of international tourist motivation and tourist satisfaction. International Journal of Research-Granthaalayah, 3(7), 1-11. DOI: 10.29121/granthaalayah.v3.i7.2015.2976

[16] Islam, N. (2012). New age orientalism: Ayurvedic 'wellness and spa culture', Health Sociology Review, 21(2), 220-231.DOI: 10.5172/hesr.2012.21.2.220

[17] Kiatkawsin, K., \& Han, H. (2017). An alternative interpretation of attitude and extension of the value-attitude-behavior hierarchy: The destination attributes of Chiang Mai, Thailand. Asia Pacific Journal of Tourism Research, 22(5), 481-500. DOI:

[18] Kocic, M., \& Radakovic, K. (2019). The implications of the electronic word-of-mouth communication in choosing a wellness offer, Economic Horizons, 21(1), 43-56. DOI: 10.5937/ekonhor1901043K

[19] Lai, I. K. W., \& Hitchcock, M. (2017). Sources of satisfaction with luxury hotels for new, repeat, and frequent travelers: A PLS impact-asymmetry analysis. Tourism Management, 60, 107-129. DOI: 10.1016/j.tourman.2016.11.011

[20] Loke, Z. (2020). Investigation of Medical - and Wellness Tourists of a Hungarian Spa to Explore Relationships Between Service Quality, Customer Satisfaction, and Loyalty. Deturope, 12(1), 102-118.

[21] Loureiro, S.M.C., Almeida, M., \& Rita, P., (2013). The effect of atmospheric cues and involvement on pleasure and relaxation: the spa hotel context. International Journal of Hospitality Management, 35, 35 43. DOI: 10.1016/j.ijhm.2013.04.011

[22] Majeed, S., Lu, C., Majeed, M., \& Shahid, M. N. (2018). Health resorts and multi-textured perceptions of international health tourists. Sustainability, 10(4), 1063. DOI: 10.3390/su10041063

[23] Mondok, A. (2019). New generations - new trends in spa industry, Economica 10(2), 21-26.

[24] Nannally, J.C. (1978). Psychometric Theory, Second ed. McGraw-Hill, New York.

[25] Peng, N., Chen, A., \& Hung, K., (2017). The effects of teppanyaki restaurant stimuli on diner's emotions and loyalty. International Journal of Hospitality Management. 60, 1-12. DOI: 10.1016/j.ijhm.2016.09.010

[26] Ristic, D., Vukoicic, D., Nikolic, M., Milincic, M., \& Kicović, D. (2019). Capacities and energy potential of thermal-mineral springs in the area of the Kopaonik tourist region (Serbia). Renewable and Sustainable Energy Reviews, 102, 129-138. DOI: 10.1016/j.rser.2018.12.005

[27] Sapic, S., Furtula, S., \& Durkalic, D. (2018). Prestige and national identity as predictors of food products purchase. Economics of Agriculture, 65(2), 643-657., DOI:10.5937/ekoPolj1802643S.

[28] Silvestri, C., Aquilani, B., \& Ruggieri, A. (2017). Service quality and customer satisfaction in thermal tourism. TQM Journal, 29 (1), 55-81. DOI: 10.1108/TQM-06-2015-0089

[29] Smith, M. K., \& Diekmann, A. (2017). Tourism and wellbeing. Annals of Tourism Research, 66, 1-13. DOI: $10.1016 /$ j.annals.2017.05.006

[30] Szromek, A. R., \& Wybranczyk, K. (2019). Proposal of value for customer of spas: Expectations of Spa patients and tourist in polish spas. Sustainability, 11(13), 3598. DOI: 10.3390/su11133598

[31] Thawornwiriyatrakula, W., \& Meeprom S. (2020). Antecedents of Tourist Loyalty in Health and Wellness Tourism: The Impact of Travel Motives, Perceived Service Quality, and Satisfaction. International Journal of Innovation, Creativity and Change, 11(10),300-315.

[32] Tomic, N., \& Kosic, K. (2020). Developing the Spa Assessment Model (SAM) and its application on the Kopaonik-Jastrebac spa zone (Serbia). Tourism Management Perspectives, 36, 100753. DOI: 10.1016/j.tmp.2020.100753

[33] Topalovic, S., \& Marinkovic, V. (2020). A multidimensional approach to the analysis of perceived value in tourism. Hotel and Tourism Management, 8(1), 49-58. DOI: 10.5937/menhottur2001049T

[34] Tsai, H., Suh, E., \& Fong, C., (2012). Understanding male hotel spa-goers in Hong Kong. J. Hospitality Mark. Manage. , 21 (3), 247-269. DOI: 10.1080/19368623.2012.624295 
[35] Valjarevic, A., Srecković-Batocanin, D., Valjarević, D., \& Matović, V. (2018). A GIS-based method for analysis of a better utilization of thermal-mineral springs in the municipality of Kursumlija (Serbia). Renewable and Sustainable Energy Reviews, 92, 948-957. DOI: 10.1016/j.rser.2018.05.005

[36] Valjarevic, A., Vukoicic, D., \& Valjarevic, D. (2017). Evaluation of the tourist potential and natural attractivity of the Lukovska Spa, Tourism Management Perspectives (22), 7-16. DOI: 10.1016/j.tmp.2016.12.004

[37] Vildova, E., Martincík, D., Tluchor, J., \& Jakubíkova, D. (2015). Measuring customer satisfation and loyalty in SPA companies. Marketing \& Trade, 18(1), 151-168. DOI: 10.15240/tul/001/2015-1-012

[38] Vukovic P., Cavlin G., \& Cavlin M. (2015). Complementarity in the development of rural tourism with the development of thermal baths, spa and wellness tourism, Economics of Agriculture, 62(1), 259270.DOI: 10.5937/ekoPolj1501259V

[39] Zhang, Y., \& Xiong, Y. (2020). A culture-oriented model of consumers' hedonic experiences in luxury hotels. Journal of Hospitality and Tourism Management, 45, 399-409. DOI: 10.1016/j.jhtm.2020.07.009

Received: 2021-03-03

Revisions requested: 2021-03-25

Revised: 2021-06-15 (3 times)

Accepted: 2021-08-25

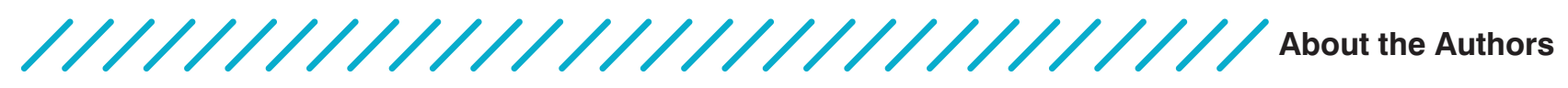

Marija Lakićević

University of Kragujevac, Faculty of Hotel Management and Tourism in Vrnjačka Banja, Serbia marija.lakicevic@kg.ac.rs

Marija Lakićević has been working at Faculty of Hotel Management and Tourism in Vrnjačka Banja from its establishment, i.e., from 2011. Her first position was the assistant for a narrow scientific field of General Economics, and in 2013 she obtained the title of assistant professor, and in 2020, an associate professor also for the narrow

scientific field of General Economics. She is the subject lecturer on the following teaching-scientific subjects: Basics of Hotel Management and Tourism (BAS), Tourist Transportation Management (BAS), Special Interest Tourism (BAS), Cultural Tourism

(BAS) and Tourism and Space (DAS). She is a mentor for final theses on basic academic studies, as well as a member of numerous committees for final and graduate master theses. Marija Lakićević has published numerous scientific, authored and coauthored papers in the field of tourism.

Danijela Pantović
University of Kragujevac, Faculty of Hotel Management and Tourism in Vrnjačka Banja, Serbia danijela.durkalic@kg.ac.rs

Danijela Pantović holds a PhD degree in Economics, obtained at the Faculty of Economics, University of Kragujevac in 2021. She works as an assistant professor at the Faculty of Hotel Management and Tourism in Vrnjačka Banja, University of Kragujevac, Serbia. She has had a number of papers published in journals and international conferences proceedings. Her main areas of interest are Hotel Management and Tourism, Cultural Tourism and European Union Tourism.

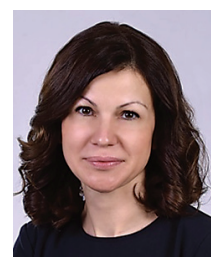

\section{Aleksandra Fedajev \\ University of Belgrade, Technical Faculty in Bor, Serbia afedajev@tfbor.bg.ac.rs}

Aleksandra Fedajev holds a doctoral degree from the University of Kragujevac in the area of Economics and she received this scientific degree in the year of 2015. Since the year 2008, she has been working at the Technical Faculty in Bor, University of Belgrade and, now she is an associate professor, teaching the following subjects: Bases of

business economy, Bases of market economy and Planning and control of costs. Her areas of interest are economic development, economic policy, business economics and business environment. She is the author or co-author of two books and numerous scientific papers in international and national journals, as well as in proceedings from

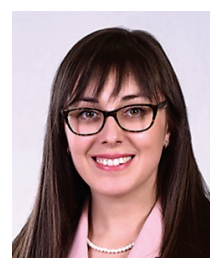
international and national conferences.

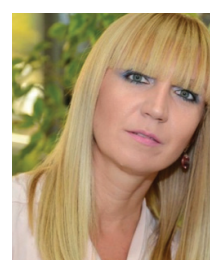

